\title{
FER FRONT A LA TRANSICIO DE L'EDUCACIO A LA FEINA. UN PROBLEMA CADA VEGADA MES COMPLEX PER ALS JOVES
}

\author{
Gerard Welbers \\ (IFAPLAN, Colònia)
}

\section{INTRODUCCIO}

Derryts de dues dècades de reformes estrucțurals $\mathrm{i}$ de foment dels plans d'estudi centrats en problemes interns dels sistemes educatius de la Cornunitat Europea, durant els darrers anys s'ha observat una tendència a estudiar més detíngudament el paper i les possibles funcions de l'educació en un context econòmic i social que evoluciona tàpidament. La preparació per a la vida en general $i$, especialment, per a la vida dins el món del treball ha esdevingut un nou desafament per als sistemes d'educació establerts, que durant molt de temps s'han ocupat principalment de desenvolupar la capacitat acadèmica i augmentar els coneixements dels estudiants, sense preocupar-se gaire de com s'aplicaria tot això a la tealitat canviant de fora de l'escola.

Aquest article vol descriure i analitzar alguns aspectes dels problemes relacionats amb el pas dels joves de l'escola al treball. Especialment, reflecteix els antecedents de la primera sèrie de projectes pilot duts a terme per la Comunitat Europea (1976-1982) per tal d'ajudar els joves a preparar-se per a la vida i la feina dins el món adult..

1. Els resuitats detailats d'aquest Programa d'Acció no es presenten en aquest article. Liur documentació completa és en una sèrie de reportatges i publicacions. Basat en els resultats d'aquest primer programa, començà el setembre del 1983 uñ 
«Papers»: Revista de Sociologia

\title{
1. PANORAMICA GENERAL DEL PROBLEMA DE LA TRANSICIO
}

L'empenta del Programa d'Acció de la Comunitat que es llançà el 1976 provenia principalment de l'augment dramàtic de l'atur juvenil. 'Tanmateix, els acurats diagnòstics del problema de l'atur juvenil no es van estudiar prou per a poder arribar a plantejaments d'una política ben definida que el resolgués. La qüestió de si l'atur juvenil s'havia de veure com un problema cíclic o com el resultat de canvis estructurals més profunds va ser objecte d'una controvertida discussió que va portar a opinions bastant diferents sobre quines mesures s'haurien de prendre per a facilitar la introducció del jovent dins el món del treball. Les 30 experiències pilot del Programa d'Acció estaven encaminades a provar les possibles contribucions dels sistemes educatius a una comprensió del problema de la transició i a l'estudi de proposicions per a resoldre'l.

S'han produit canvis considerables des que es va creat la primera sèrie de projectes.

Malgrat la tendència a la consolidació de l'economia a alguns paisos, l'amenaça de l'atur no ha disminuit en general. Lluny d'això, entre l'octubre de 1980 i l'abril de 1984, el nombre d'aturats a la Comunitat Europea es va incrementar més de 5 milions, des d'uns 7 milions a 12,5 , és a dir, un augment del $70 \%$. Més del $40 \%$ dels aturats són joves de menys de 25 anys. Sis de cada deu joves sense feina són dones. La manera com aquesta tendència evolucionarà en el futur i si s'haurà d'acceptar un alt percentatge d'atur a tots els països són qüestions que encara estan per tesoldre.

No obstant això, aquesta incertesa podria molt bé convertir-se en un element estable a l'hora de planificar el futur. Si la viabilitat i l'eficiència tecnològica esdevenen els criteris més importants, l'aprovisionament de la

segon programa de Transició que inclou també 30 projectes pilot aplicats a tots els deu estats membres de la Comunitat Europea.

Pet a obtenir més informacio sobre el primer i el segon Programes d'Acció sobre la Transició, podeu adreçar-vos a les adreces següients:

\section{Comission of the European Community \\ Directorate General V \\ 200 Rue de la Loi \\ B - 1049 Bruxelles}

o bé

\author{
Programme Information Office \\ IFAPLAN Bruxelles \\ Square Ambiorix 32 \\ B - 1040 Bruxelles
}


major part de béns que la nostra societat necessita es produirà amb una força laboral molt més petita que l'actualment feta servir. Es podria argüir que, històricament, quan les innovacions tecnològiques han fet acomiadar gent, a la fi sempre han tornat a trobar feina en un altre sector. Però aquests acomiadaments sempre han produït molt de trasbals als individus afectats $i$ actualment la naturalesa i proporció del desenvolupament tecnològic canvien més radicalment i més de pressa que en períodes anteriors. El temps de què hom disposa per a adaptar-se a les noves situacions s'escurça cada vegada més. En èpoques anteriors, les innovacions tecnològiques van fer sortir un nombre elevat de gent dels sectors de la indústria i la confecció i molts d'ells han anat a parar al sector de serveis, que està creixent. Avui, àdhuc en aquest camp en expansió s'utilitzen cada vegada més tecnologies noves i més eficients, la qual cosa implica una altra vegada una necessitat més tedülda de mà d'obra.

Sembla ser que la introducció de nova tecrologia i d'una nova organització laboral té una altra conseqüència, que és la tendència a una divisió més accentuada del treball en especialitzat $i$ no especialitzat. A part d'una quantitat relativament petita d'especialistes altament qualificats, un nombre creixent de sectors del món laboral només requereixen gent per a activitats rutinàries que no necessiten la preparació dels treballadors que els ocupen avui. La sensació d'estar massa especialitzat per a la feina que es fa $\dot{i}$ com a consequència, el fet de no haver de demostrar la capacitat professional es tradueixen sovint en una pèrdua de motivació $i$ a vegades en un rebuig conscient del treball.

Entre el jovent s'observa una tendència a adoptar actituds més crítiques davant les ofertes de treball existents, malgrat la difícil situació laboral. No accepten tan fàcilment que el seu entorn els pugui infuir o manipular; posen en dubte el paper de l'educació i l'assessorament en la selecció d'uns joves i el rebuig d'uns altres; creuen que el fet d'acceptar el mercat actual de treball com una cosa immutable no té gaire sentit. Aquest fenomen pot no ser evident a tot arreu, però es fa evident allà on es comencen a dur a terme maneres noves de sobreviure econòmicament i socialment. Aquesta «cultura de la supervivència» és vista amb desconfrança per part d'aquells que donen suport als sistemes ja establerts; malgrat això hom pot adduir que demostra un grau de maduresa social molt poc valorat. S'hauria de reconèixer el perill que s'arribi a crear un trencament cultural (cultural gap) entre aquells qui accepten l'organització tradicional del món del treball i aquells qui no l'accepten.

Aquests moviments porten a la conclusió que els períodes d'atur (millor dit, «períodes sense feina pagada fixa») tant després d'acabar l'escolarització com durant qualsevol moment de la vida laboral, s'hauran de veure 
com una possibilitat real i no com abans, és a dir, com un cas d'excepció d'aquells qui es troben en una situació econòmica difícil o que no estan dotats de preparació. Com més es basa la prosperitat en el consum creixent de béns $i$ serveis, que les màquines automàtiques o semiautomàtiques poden produir molt bé, més real sembla aquesta perspectiva.

Sorgiran nous camps de l'activitat ocupacional on la gent podrà trobar feina i guanyar-se la vida. Però la seva natura encara no està definida. No és clat si les polítiques convencionals d'economia de mercat i de treball podran tornar a establir la plena ocupació i dominar la dinàmica d'un mercat de treball que cada vegada és més complicat. Darreta la «situació oficial» que presenten les estadístiques de l'atur s'estan prođuint uns certs processos que normalment s'escapen de la vigilància dels sistemes establetts de regulació de l'oferta i la demanda. Evolucionen mercats marginals i perifèrics que donen feines temporals (a vegades sense declarar, per taons d'impostos), les quals no ofereixen cap futur al treballador. A més, s'estan creant algunes classes de feina no tradicionals (com els «collectius de joves») que estimulen la creativitat individual i la motivació i que contribueixen a establir alternatives a llarg termini per al mercat laboral actual; la línia divisòria entre els aspectes negatius i els positius no és sempre fàcil de dibuixar. El problema es planteja en termes de si les noves polítiques del futur hauran de fixar-se més a organitzar i estructurar aquest món marginal o a ignorar-to o suprimir-lo. Una conseqüència evident de tot això és que els sistemes de collocació i assessorament haurien de tenir en compte l'existència d'aquests llocs de treball.

Fins ara s'ha fet molt poc a l'hora de preparar la gent a adaptar-se a una certa inseguretat respecte a la tradicional feina estable. El fet d'informar els joves d'aquesta situació posa els nostres sistemes educatius en un greu dilema. Durant les últimes dècades la publicitat que demanava més i millor educació $\mathbf{i}$ fins la mateixa ideologia educativa han estat lligades amb el missatge implícit que diu que aquells qui estan més ben preparats són els qui obtenen els millors llocs de treball. Això acostuma a anat junt amb la interpretació implícita segons la qual tot allò que es necessita per a tenir èxit en la futura vida professional es pot adquirir d'una sola vegada abans de començar la vida laboral. Potser algú trobarà que és cínic el fet d'adduir al mateix temps que una de les tasques futures importants de l'educació hautia de ser també la preparació pet tal que la gent es pugui adaptar més bé a la situació d'atur.

Admetre que la vida laboral pugui començar amb un lloc de treball més poc remunerat o àdhuc amb l'atur $i$ preparar sistemàticament els joves per a aquesta realitat pot provocar un impacte negatiu en les seves motivacions. Pot fomentar la sospita que falla alguna cosa tespecte a les com- 
pensacions promeses per complir amb el sistema educatiu i així posar en petill el significat $i$ l'adequació de tot el procés educatiu.

En el fons aquest dilema no es pot resoldre sense fer una reconsideració general del paper i la funció de l'educació. Cal començar a pensar que el temps que els joves passen a escola $\mathrm{i}$ el subsegüent període de capacitació professional només són el començament d'un procés educatiu a llarg termini. No podem espetar que una pteparació completa per a tota una vida professional sigui en tealitat exclusivament el resultat d'aquesta fase inicial. Cal abandonar el model tradicional, que creu que l'educació només ha de ser per als joves $\mathrm{i}$ el treball només per als adults. Lluny d'això, l'educació sistemàtica s'ha de concebre com un element integrant $i$ repetitiu del treball i de la vida adulta que ajuda a mantenir els coneixements $i$ la competència de l'individu al nivell que exigeixen una realitat que canvia acceletadament $\mathrm{i}$ les seves pròpies necessitats canviants, i que a més ha de subministrar una base sòlida per a preparar-se per a les noves etapes de la vida. Això inciou educació durant tota la vida amb la possibilitat d'un aprenentatge personal continu, d'oportunitats de considerar les alternatives als models de «carrera professional» tradicionals, $i$ amb un ús més profitós d'aquelles qualitats personals que en els llocs de treball que existeixen actualment no s'aprofiten prou.

Hem de reconsiderar els conceptes d'atur i d'ocupació. Feines a temps parcial, compartides amb un altre treballador, teduccions dràstiquues del nombre d'hores de treball, mitja jornada o jubilació abans d'hora; tot això són mesures que guanyatan importància en el futur i faran incrementar el temps que hom tindrà per a altres coses fora del treball temunerat. Caldrà escoltar amb més atenció les raons d'aquells qui creuen que el creixement hautia de tenit lloc dins el camp de les activitats socials i de miIlora de la qualitat de vida més que en el consum de béns industrials. Els nous conceptes de creació de llocs de treball poden ajudar a estructurar aquestes perspectives que encara són marginals. Si l'atur, en el sentit convencional del terme, ha de mantenir-se durant molt de temps a nivelis alts, cal preguntar-se si no caldria donar preferència a noves formes d'inversió pública per a crear llocs de treball sobre el pagament del subsidi d'atur.

Es podria suposar que aquestes tendències no només donatan un nou significat al concepte de treball (per exemple, que no sigui considerat com una part $\tan$ inseparable dels avantatges socials de l'individu i que sigui un indicador menys important de l'èxit i el prestigi socials), sinó que també a llur torn portaran a una nova definició de la situació dels aturats. Un teconeixement públic cada vegada més accentuat pels llocs de treball de nova creació, les iniciatives subvencionades i les activitats «transitòries», equipa- 
rant-los en valor social als llocs de treball tradicionals, podria ajudar a aquesta tasca. L'increment que s'espera en el temps de «lleure» de molta gent, juntament amb una politica més activa respecte al lleure, podria contribuir també a reduir la distància social entre aquells qui realment tenen feina $i$ aquells qui no en tenen. L'atur s'acabaria veient no tant com un fracàs personal i social sinó com un petíode transitori en una vida labotal d'una variació molt més gran.

Això que hem dit abans no només és vàlid per als joves ni el problema de la transició es limita a aquells que acaben l'escola; els adults també es troben en una situació de transició constant. No obstant això, la població més jove és la que probablement aportarà noves actituds a tenir en compte a l'hora de resoldre aquest problema. Aquest fet condueix a una altra sèrie de factors que constitueixen el marc on hem d'enquadrar el problema de la transició tant dins el món del treball com a la vida adulta. En les generacions adolescents estan naixent noves concepcions de la vida laboral i adulta, diferents de les de la societat dels grans (pares, empresaris, educadors, polítics). Els valors i les necessitats dels joves tal com ells mateixos els experimenten $i$ expressen contrasten amb els valors que de manera implícita hi ha darrera de moltes accions encaminades a preparar-los per a la transició. Segons l'opinió d'un nombre creixent de joves, l'objectiu final del període de transició no és tant el fet de poder trobar una feina com arribar a una forma més rica d'assolir la satisfacció personal i social. Quant a això, hom veu també la transició com una integració social rnés satis. factòria dins l'status adult.

Cada vegada més es pensa en les perspectives del futur desenvolupament personal com una manera de viure individual més que com un tipus específic de lloc de treball. El treball remunerat es veu com una forma d'assolir la independència econòmica mínima, però es rebutja amb freqüència si no ofereix cap oportunitat real de realització $i$ autonomia. L'èrnfasi que es concedeix a les bones relacions socials, a les actituds de colla. boració, a la solidaritat entre els homes, a un ambient que estimuli l'aprenentatge dins el lloc de treball, el desig de participar a l'hora de prendre decisions, $i$ l'interès creixent pels llocs de treball no tan ben remunerats però socialment importants, així com pels que pertanyen a les noves empreses petites independents, són signes d'una mateixa cosa. L'especialització professional, l'adquisició d'actituds més comercialitzables i un pla «materialistà» de vida professional sovint passen a un segon pla.

Unes tendències així no es poden deixar de banda; la manera més usual de preparar els joves per a la transició és massa restringida, atès que s'hauran de trobar alternatives d'integració si les indústries que donen feina no poden fer front a la demanda tant en qualitat com en quantitat. S'hau- 
ria de mantenir un diàleg sobre els nous valors entre tots els protagonistes, de manera que el jovent pugui negociar el seu propi contracte amb el sistema educatiu, els empresaris i la societat.

La preparació del jovent de cara a la vida laboral i a acoplar-se al canvi dins aquesta vida no es pot considerar que siguin simplement una qüestió de donar-los la competència professional adient, sinó que el problema es torna a plantejar en la necessitat de trobar nous mètodes $i$ formes de socialització $\mathrm{i}$ en la responsabilitat ineludible que els sistemes educatius hi tenen, deixant de banda la situació econòmica. Les idees d'una educació que s'anés repetint regularment (o educació permanent) i d' «alternança» podrien constituir un matc adient $i$ coherent de resoldre el problema; els lligams evidents amb la mà d'obra i les polítiques d'ocupació necessiten intents més radicals per a reforçar la cooperació i la coordinació.

Els objectius i les limitacions d'aquest article exclouen la discussió en detall de les diverses teories sobre la telació entre el treball i l'educació, dins les quals els problemes de transició es consideren en general com una relació inadequada entre els sistemes d'educació i els d'ocupació, o com un matrimoni mal avingut entre el mercat de treball i el «producte» de l'educació, si es pot dir així. No obstant això, sembla que les teories generals més importants dins el camp de l'economia, la política social, les previsions de mà d'obra $i$ les polítiques d'ocupació no han sabut predir els pro. blemes que en un passat recent s'han fet evidents; també semblen incapa* ces de donar una explicació coherent $i$ comprensiva de la situació que avui hem d'afrontar.

Ha esdevingut evident que no n'hi ha prou amb els models establerts per a donar una base teòrica global al difícil problema de la transició. La necessitat de combinar l'educació i l'ocupació de manera que satisfaci tant l'individu com la societat sembla anar més enllà de les perspectives de les teories actuals. Es necessita un marc nou i més ampli per tal d'entendre les interaccions entre tots els factors importants dins la transició i per tal d'extreure conclusions de cara a una política àmplia $i$ coherent a llarg termini, que es basi en les dades analítiques de diverses ciències, com l'economia, les ciències socials i la pedagogia.

Sembla poc probable que puguetn disposar d'un marc tan ampli a curt termini. Pet aquest motiu, la present anàlisi es limita deliberadament a observar i descriure les dificultats que troben els joves durant el període de transició. No es basa tampoc en cap teoria en concret sinó que vol centrar-se en els problemes $i$ les necessitats dels individus afectats més que en les necessitats més abstractes dels sistemes d'educació i treball, o de tota la societat en general.

Cal tenir present una orientació fonamental: aquest article tracta prin. 
cipalment dels problemes de la transició i no de l'atur juvenil. La idea bàsica d'una transició satisfactòria va més enllà del fet de trobar i conservar una feina, sigui la que sigui. Abasta l'adquisició i l'aplicació correcta de la capacitat personal que hom necessita a l'hora de prendre una bona de. cisió i de fer els passos necessaris per a assolir el lioc de treball que cada individu creu que li correspon, per exemple aquella feina que permeti una evolució personal més àmplia. Parla del foment de la motivació i l'actitud necessàries per a esdevenir una part constructiva i dinàmica del món del treball; inclou dins això la preparació professional addient, un mínim bàsic d'aptituds i preparació i la capacitat d'adaptar-se a una situació d'atur.

Des d'aquesta perspectiva, la transició al món del treball no sembla ser simplement un problema transitori que sorgí a partir de la crisi de l'ocupació, encara que sens dubte aquesta el tragué a la llum. El problema constant consisteix a capacitat els joves perquè, si més no, puguin sobreviure o, més encara, esdevenir membres satisfets $i$ competents d'una societat que és més complexa i competitiva cada vegada i que afronta canvis més $\mathrm{i}$ més ràpids.

\section{EL MARC DE REFERENCIA. TIPOLOGIA GENERAL DE LES POSSIBLES SITUACIONS PROBLEMÃTIQUES}

Per tal de poder fer front a les dificultats de la transició i establir-se d'una manera satisfactòria dins el món laboral adult, cal disposar de dues condicions bàsiques:

- L'individu ha de tenir al seu abast els mitjans personals (en qües. tió d'aptituds i qualificació) que li permetin d'identificar els llocs de treball adients, sollicitar-los i ser capaç, en la pràctica, de satisfer les exigències del lloc de treball que finalment haurà acceptat.

- Tan important, si més no, és la necessitat d'elaborar una llista coherent de les aspiracions personals, una perspectiva dinàmica del model de vida propi de cadascú dins la societat, que en ell mateix faci que l'adquisició de coneixements i qualificacions tingui sentit per a l'individu. En altres paraules, el jove necessita una idea clata dels elements que hi ha a la vida laboral de l'adult pels quals val la pena de lluitar i que constitueixen la base més sòlida de la motivació i les actituds constructives vers la nova etapa de la vida després de la transició des de l'escola.

Ambdues condicions són necessàries; amb una de sola no n'hi ha prou. Un jove que aspiri a ser un dependent de botiga però que no tingui uns 
coneixements elementals bàsics difícilment trobarà feina en aquest terreny. Igualment, un estudiant ben preparat sense cap motivació ni idea de com fer servir la seva preparació de forma econòmicament satisfactòria i que es trobi anant d'un lloc de treball a un altre finalment serà rebutjat per part dels empresaris per poca formalitat.

Ambdues condicions són complexes; poden ser acomplides en un dels seus aspectes $i$ no en un altre a un mateix temps. El grau en què es poden satisfer pot variar també amb el pas del temps i tant els mitjans com les aspiracions poden evolucionar dinàmicament. Cada condició s'allarga en una seqüència contínua on hom pot identificar totes les gradacions possibles en relació a la naturalesa de les aspiracions individuals i/o la possessió dels mitjans adients.

Les dues condicions bàsiques reben en elles mateixes la influència del marc contextual en què han de dur-se a la pràctica. Aquest marc es refereix principalment a tres àrees diferents: el context sòcio-econòmic, allò que els sistemes educatius ja cobreixen i el grau de cooperació tant entre el personal i les institucions del sistema educatiu com entre l'educació i altres terrenys d'actuació social i econòmica. Així, pel que fa referència als mitjans, el fet que un jove pugui utilitzar la preparació professional que la feina exigeix depèn de la possibilitat de preparació adient; si aquesta preparació podrà ser utilitzada tealment depèn de les facilitats que hi hagi a l'hora d'aconseguir el lloc de treball apropiat. De la mateixa manera, la construcció d'un model dinàmic d'aspiracions a llarg termini per a la vida adulta i laboral serà molt més fàcil si hom procedeix d'una família estable amb un ambient estimulant que si es ve d'una familia trencada. Certament, l'accés a ura documentació curosament elaborada sobre les perspectives professionals, juntament amb un servei ben promogut de consell i guia, facilita l'acompliment de les ambicions personals.

Per tant, es pot deduir un nombre elevat de combinacions per a les condicions bàsiques dins els distints contextos.

Aquest simple esquema pot ajudar-ne la comprensió: 


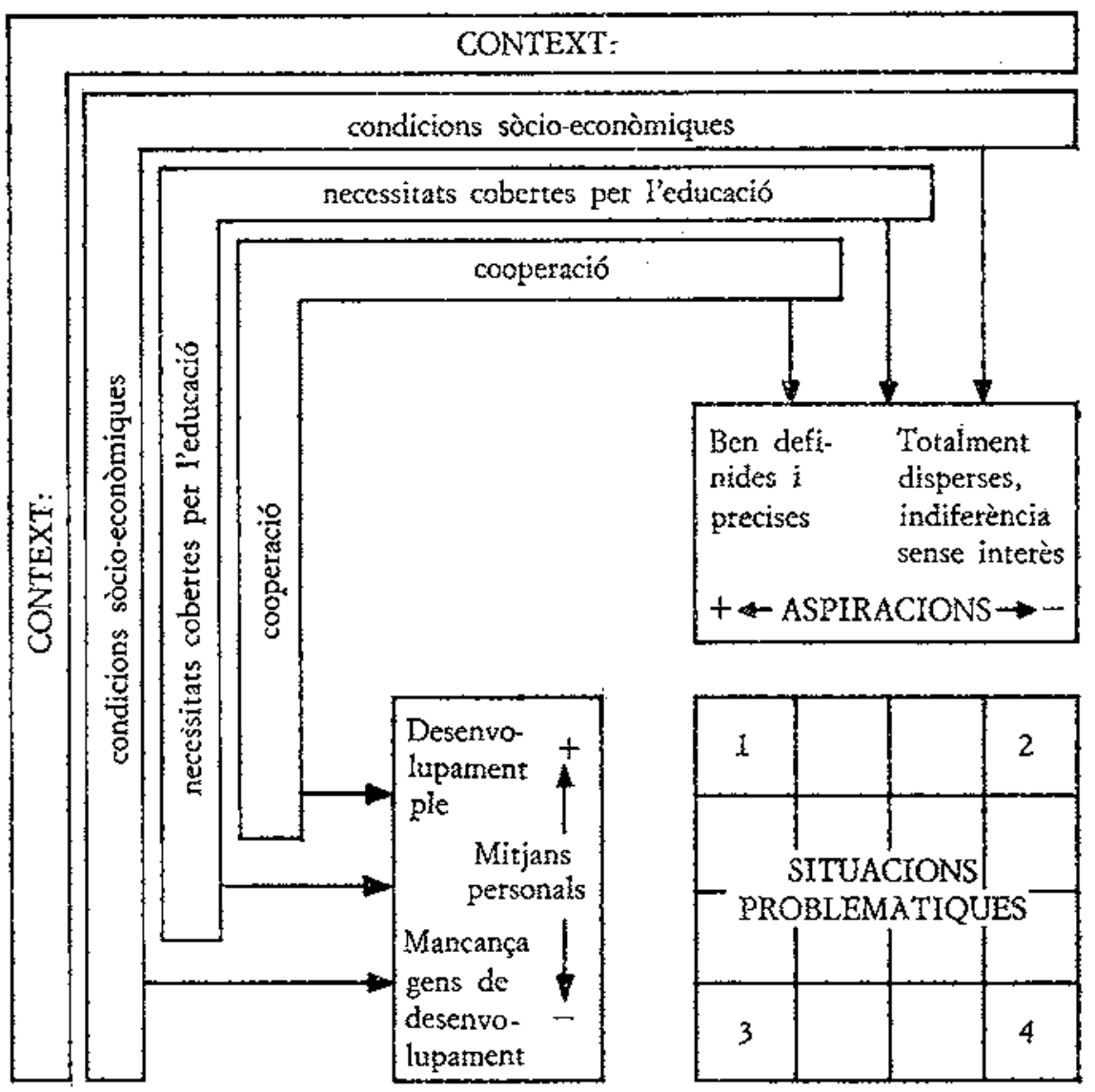

Als quatre extrems hom pot identificar els següents tipus diferents de situacions problemàtiques generals:

- A la situació núm. 1, les aspiracions ben elaborades i les motivacions en relació a la vida laboral troben el seu patallelisme en una sèrie gairebé completa de mitjans eficaças a l'abast de l'individu. Aquest seria el cas, per exemple, d'un estudiant brillant que acaba de deixat l'escola, que té per clar objectiu una vida professional dins el terreny de l'enginyeria mecànica, que té un bon nombre de possibilitats d'aprenentatge a escollir dins el seu entorn local, el qual a la vegada ofereix perspectives de treball adients $i$ es beneficia dels processos d'aprenentatge eficaços $i$ adequats. 
Aquest sembla ser el cas ideal; tanmateix aquesta no és la situació normal de molta gent que es prepara per entrar dins el món del treball. Cada vegada sorgeixen del context més problemes que l'individu no pot controlar: per exemple, una preparació adient per a la vida laboral no garanteix que hom no pugui trobar-se sense feina en períodes en què la demanda de mà d'obra decreixi. Per aquest motiu, i a causa en part de la situació econòmica actual, un nombre creixent de joves relativament ben preparats troben dificultats que abans només afectaven els «grups de risc» més poc preparats que ells.

- La situació núm. 2 es refereix als joves que potser tenen les aptituds considerades necessàries per a trobar feina però que no les fan servir per manca d'ambició o per la incapacitat de veure què tenen a l'abast o de valorar allò que és una possibilitat real. Sembla que en alguns paisos hi ha un nombre creixent d'escolars ben preparats que, després d'haver acabat els estudis, no poden entrar a l'edicació superior ni al mercat laboral (és a dir, a l'ocupació o a l'atur oficial). Molts d'ells poden anar a parar al «mercat laboral secundari» amenaçats per la inestabilitat creixent de les condicions de vida, $i$ en perill de perdre la confrança de la societat en la validesa de llur preparació.

- La situació núm. 3 reflecteix el cas dels joves que tenen una motivació relativament forta vers el treball i una idea més o menys concreta del tipus de feina que volen, però que no poden disposar dels mitjans necessaris per tal d'assolir llurs objectius. Un exemple d'això podria ser un treballador jove emigrat que vulgui esdevenir mecànic de cotxes però que una institució d'ensenyament no pugui admetre a causa de les seves deficiències lingüístiques. També teflecteix el problema de l'obrer jove sense títols que, malgrat l'aprenentatge que ha adquirit per mitjà de l'experiència, es veu marginat de qualsevol ptomoció dins el seu ofici a causa de la manca de qualificacions escrites.

- La situació núm. 4 descriu el problema d'aquells joves que sovint hom coneix com «els marginats». Aquesta situació es caracteritza per l'absència tant d'aspiracions personals com de possibilitats d'accedir als mitjans adequats. El cas extrem és el jove que demostra una indiferència total a les possibles perspectives laborals, que ha fracassat a l'escola, que no té ni feina ni preparació $\mathrm{i}$ que arriba fins a rebutjar qualsevol intent de reintegració per part dels sistemes educatius o de treball. És el cas dels joves que no tenen ja cap mena de confiança en la possibilitat d'èxit personal en una vida professional normal $i$ que per aquest motiu se separen completament del sistema en què han fracassat. 
Les situacions problemàtiques que hem descrit més amunt no són tan evidents ni tan ben definides en la pràctica com ho són en la teoria. Molts joves que tenen dificultats en la transició se situen de fet entre les situacions més extremes. L'objectiu de la classificació dins aquest context no és analitzar clarament grups distints de joves sinó més aviat indicar quins són els símptomes bàsics que hi ha sota l'entrellat dels problemes de la transició dels individus afectats. L'anàlisí que segueix intentarà demostrar com aquesta tipologia general dels problemes es relaciona amb les dificultats pràctiques de la transició i les possibles maneres d'enfocar-les.

\section{QUINES SON LES DIFICULTATS PRACTIQUES DEL PERIODE DE TRANSICIO}

La manera d'entendre la vida laboral en aquest article comporta una idea més àmplia que aquella en què la feina (més concretament, la feina remunetada) es veu només com una condició prèvia necessària per tal d'as. segurat-se un status econòmic. Encara que per a un individu en concret sigui difícil d'entendre quin pugui ser el motiu de seguir treballant en una cadena en sèrie si no és guanyar allò que necessita per a viure un cop fora de la fàbrica, la finalitat del treball s'hauria de concebre més àmpliament. Cal mirar-se la vida laboral com la clau principal de la integració social, una clau que determina en bona part la importància social de l'individu i que proporciona a més les oportunitats més importants de promoció social a un elevat nombre de persones $i$ constitueix un element considerable d'integració social, particularment durant el periode de transició.

Per tant, el paper que el treball porta a terme és extremament complex. La preparació per al treball en aquest context no inclou solament l'adquisició de la capacitat professional adient. Exigeix també la pràctica i l'aprenentatge d'altres habilitats i coneixements, que permetin a l'individu d'entendre aquest paper complex i de fer ús actiu de totes les oportunitats de seguir el seu propi camí dins el món laboral; aquesta actitud contrasta amb el fet de conformat-se amb allò que se li ofereix.

La següent classificació de dificulłats no pretén ser exhaustiva. Només intenta exemplificar, des del punt de vista individual, quins són els obstacles que fan que el camí de l'educació a la vida laboral sigui tan enganyós. Per suposat, no tots els joves xoquen amb cadascun dels obstacles; però tots n'han d'afrontar uns quants. 


\subsection{Prendre les decisions correctes}

El tipus d'oportunitat que un context donat ofereix a l'hora de trobar $i$ assegurar-se una posició a la vida laboral depèn en gran mesura de factors que lindividu no pot controlar. El fet de si aquestes oportunitats són utilitzades i fins a quin punt ho són és tanmateix el resultat de les decisions personals que hom ba de prendre durant els anys de preparació i treball d'una vida professional. Sens dubte, el període tmés crític és el de la transició real, on s'acumulen una gran quantitat de situacions en què cal prendre una decisió amb importants conseqüències per a la vida futura. Una complicació molt característica sorgeix del fet que moltes decisions d'aquest periode no es poden basar en l'experiència personal, sinó que només depenen de les aspiracions personals de l'individu o de les seves expectatives de futur i dels conselis i la valoració d'altres persones.

Molts joves, en la transició, i especialment durant el període de l'adolescència, no són en realitat conscients de la personalitat que neix dins seu. Moltes vegades saben més bé què és allò que rebutgen que no pas allò que desitgen $i$ que tealment podrien obtenir. Els joves que pateixen per causa d'un sistema escolar on sempre fracassen (segons els patrons de classificació tradicionals) sovint no tenen idea de l'existència d'alternatives; se senten particularment abandonats si la seva sortida més immediata cap al treball està bloquejada per manca de places litures o si les feines que troben no corresponen de cap manera a llurs possibilitats o aspiracions. Sovint se senten agafats entre l'experiència «positiva» d'haver deixat l'escola i l'expetiència frustrant de tractar de trobar feina. Adhuc aquells que van bé en els estudis es troben en una situació semblant si no hi ha cap manera de mostrar-los les oportunitats que ells podrien i voldrien potser aprofitar: és millor quedar-se a l'escola? Amb quin objectiu? Hi ha alguna perspectiva més optimista? Els joves es veuen obligats a escollir entre opcions prefabricades, cap de les quals no pot arribar a ser allò que desitgen; no tenen cap ajut que els permeti de posar en pràctica una alternativa personal.

La dependència dels consells externs fa que els joves hagin d'aftontar un problema molt important per a ells, que és el d'on aconseguir aquests consells. Als seus ulls, qui els coneix més bé, ¿és més competent i mereixedor de confança? ¿Els pares, que potser estan massa afectats per les seves pròpies intencions envers els seus fills o qute potser no hi tenen cap interès o es veuen impotents a l'hora de donar consells? ¿El mestre, que mai no ha posat un peu fora de l'àmbit de l'escola? ¿Els companys, que pateixen els mateixos problemes? ¿EI personal de serveis especialitzats, que els sem- 
bla tan Ilunyà i que acostuma a veure els problemes des d'un punt de vista purament administratiu?

La divisió existent de les responsabilitats d'ajut durant el període de transició entre diferents agències no ajuda els joves a l'hora d'enfocar la seva situació globalment. Per a ells, les qüestions que s'han de resolḋe formen un complex coherent, la interrelació entre les quals és gairebé impossible de comprendre. Així, troben una gran dificultat quan molts dels seus consellers només es veuen capacitats per a ajudar en una part del complex; ningú no té una resposta global. El personal de moltes organitzacions diferents comparteix la responsabilitat de tractar de tesoldre els problemes del jove durant la transició i la presa de les decisions adients, sense que moltes vegades els coneguin. No hi ha cap «advocat» dels joves que, coneixent-los a elis i la seva situació, canalizzi els seus problemes cap a les otganitzacions adequades.

Adhuc allà on es donen consells específics i s'exposen suposades alternatives en la presa de decisions, aquestes són incomprensibles o enganyoses per als joves. Per exemple, la informació específica sobte cursos i possibilitats laborals dins les tècriques de control de la producció podrien arribar a ser una perspectiva prometedora, però potser no tindria sentit per a un jove que no tingui ni idea de què significa la producció en sèrie. $\mathrm{O}$ una informació del tipus «dins el camp de la fabricació de paper les dones troben feina per a aprestar, classificar, agrupar, amuntegat $i$ fer paquets» podria ser veritat de fet, petò dóna la falsa impressió que aquest tipus de feina és especialment adequat per a noies.

Quan hom pregunta als joves que han acabat l'escola quina ha estat la contribució dels serveis d'assessorament i guia a l'hora de prendre decisions personals, els joves sovint recorden que van rebre molt poc ajut si no gens. Aquestes afirmacions -freqüentment en contradicció amb les estadístiques oficials sobre el nombre d'estudiants que han entrat en contacte amb els serveis especialitzats - reflecteixen les limitacions dels serveis existents.

Els joves que passen a l'acció sobre una base inadequada, sense conèixer totes les implicacions, sovint s'adonen després d'un curt període de temps que han pres una decisió errònia. Llavors es tornen a trobar a si mateixos un altre cop al punt de partida, frustrats, havent adquirit la sensació que aquesta experiència és una altra de les coses que no volen.

A alguns pailsos els serveis d'assessorament i orientació són més avançats que en d'altres; es podrien trobar també diferències molt importants entre regions distintes d'un mateix país. El punt de partida personal des d'on prendre decisions tampoc no és el mateix en tots els joves. Els estudis d'investigació demostren que, com més difuses $i$ indiferents són les seves 
aspitacions de cara a la vida futura, més esperen els joves una recompensa irmmediata per les seves iniciatives o decisions $\mathrm{i}$ menys poden o volen tenir en compte les consequències a llarg termini. Si l'única motivació és poder guanyar diners en la feina que sigui, el zesultat d'uns estudis professionals de tres anys es veu massa Ilunyà per a competit amb l'atractiu dels diners immediats procedents del treball no especialitzat, àdhuc si aquesta feina només es pot trobar al mercat «negre» de mà d'obra. En aquells casos en què no té lloc ni aquest èxit a curt termini comença aleshores un cercle viciós, en el qual l'escassa motivació fa disminuir les possibilitats d'èxit $i$ el fracàs fa baixar una altra vegada la motivació. Aquesta situació contrasta amb la d'aquells joves que tenen unes idees més àmplies i no tan fatalistes. Aquests fan projectes a Ilarg termini amb més illusió, els quals projectes els porten a considerar també alternatives que no busquen tant la recompensa immediata, però que ofereixen la possi. bilitat d'una realització més completa en els anys futurs de les seves vides, també dins l'àmbit laboral.

\subsection{Adaptació a l'atur $i$ a la inseguretat laboral}

El fracàs a l'hora de trobar feina és, sens dubte, l'expressió més dramàtica de les dificultats de la transició.

Les anàlisis dels efectes i les consequiències a curt i llarg termini sobre els joves apunten la conclusió que l'atur no es considera, per part de molts afectats, com un fenomen de masses o com un problema social i econòmic general, sinó més aviat com un cas de mala sort personal dins una situació en què la majoria encara troba ocupacions acceptables. El sentiment de culpabilitat que encara senten molts aturats a causa de la seva pròpia situació està estretament lligat amb una ètica tradicional del treball, on el treball i l'èxit en la vida professional es consideren els elements més im* portants de la vida social.

Irònicament, les opinions corrents sobre els suposats avantatges de poder consumir sense produir provenen de la mateixa ètica del treball $i$ això incrementa la mala consciència de l'aturat. Aquest sentiment produeix una texsió creixent als joves aturats: com més temps s'estan sense feina, més privats se senten d'una sèrie de condicions prèvies importants que els són necessàries per a ser plenament acceptats dins el món adult, i a més creuen que el seu fracàs personal en té la culpa.

Fer front a les sensacions de pèrdua $i$ fracàs personal és particularment difícil durant els anys de transició, en els quals, encara que aquest problema no s'arribi a plantejar, cal un esforç molt important per part dels joves 
per a adaptar-se a una nova etapa de la vida. Per aquest motiu, hom no pot veure l'atur juvenil simplement com una part del problema de l'atur en general: per als joves les conseqüències són diferents, en una gran proporció, que per als adults; aquestes difcultats exigeixen solucions diferents.

Els joves que han acabat l'escola s'adonen aviat que no se'ls concedeix un status adult immediatament. El fet que tinguin o no feina és un factor decisiu per a això. Una de les principals dificultats que els joves sense feina han d'afrontar és el fet que es veuen privats dels mitjans que creuen que els podrien assegurar una posició independent, com per exemple recursos monetaris personals i autonomia en relació a la família. Les investigacions demostren que molts joves sense feina viuen sota un gran stress en intentar aconseguir els diners que necessiten per a mantenir-se al mateix nivell que els seus companys que, gradualment, van esdevenint consumidors in. dependents: no poden mantenir una moto o un cotxe, comprar discs, sortir amb ningú, anar vestits segons la moda. Molts símbols de la desitjada autonomia social s'esvaeixen en la distància. A més, la resposta a l'autoritat dels pares i l'adaptació a les normes familiars es veuen en perill pet culpa dels joves quan aquests no troben cap compensació en una situació d'independència laboral: com més llarga és la durada de l'atur, més freqüents esdevenen els problemes familiars.

Una altra pèrdua de consequiències greus és el fet que els joves en atur resten exclosos de la nova situació d'aprenentatge que aporta l'ambient de treball. Allò que a molts joves els sembla que és avorriment és en realitat moltes vegades la sensació d'estar bloquejats en'tant que persones i àdhuc d'estar anant endarrera. Hom experimenta la situació de trobar-se en atur com extremament pobra en varietat i estímuls. Es perden les oportunitats de guanyar experiència de les noves realitats tècniques, socials $i$ econòmiques que rodegen aquells qui han arribat al treball o a l'aprenentatge pràctic. Algunes de les experiències bàsiques que hom necessiła per a la realització plena de les seves possibilitats no es poden adquirir sinó dins un context laboral. El treball és una part de la realitat global, que s'organitza d'una forma bastant diferent del món limitat de l'escola o la llar. Dins aquest món s'han d'entendre $i$ adoptar concepcions diferents de les relacions personals, del rendiment, de l'eficiència i de la disciplina. Cal aprendre noves normes $i$ fer créixer un altre tipus de solidaritat amb altri. Tot això forma part de la funció socialitzadota del treball en la seva primera etapa; per això la feina és molt més que un mitjà d'assolir la seguretat econòmica.

Mitjançant la comunicació i la comparació amb aquells qui treballen els aturats s'adonen, encara que d'una manera tan imprecisa com puguem imaginar, que s'estat deixant perdre una experiència important per a la seva 
pròpia realització personal. Com més llarg és el periode d'atur més s'adonen de l'abisme que es va obrint entre lihur situació $i$ la dels seus coneguts que treballen; les activitats de lleure que comparteixen amb aquells qui tenen feina no poden salvar aquest abisme. A la fi es produeix una reduc. ció notable dels contactes socials, la qual cosa crea noves dificultats als aturats a l'hora de seguir confiant en ells mateixos dins la relació amb altri.

Les conseqüències es fan paleses en el descens de la motivació $i$ en una ambició cada vegada més baixa per trobar una feina adient a mida que s'allarga el temps d'atur. Algunes de les dades a l'abast demostren que el nombre de sollicituds de llocs de treball que fa el jove aturat baixa signi. ficativament després d'uns quants mesos; al mateix temps creix el desig d'acceptar un lloc de treball fora del camp d'interès del començament o d'un nivell inferior a aquell a què s'aspirava en principi. Aixo ens temet a una altra implicació greu de l'atur, que no hem de subvalorar: el gradual abandonament de les aspitacions personals. Els joves que tenen una perspectiva clara de la seva vida laboral haurien de ser en general capaços de no rendir-se als obstacles a curt termini. No obstant això, com més dura el període d'atur i menys precises són les aspiracions inicials, més posen en dubte la importància dels valors professionals $i$ ocupacionals que havien mantingut prèviament. $E l$ grau de resignació que es $f a$ a vegades evident en les enquestes als joves en atur és esgarrifador, ja que, sense la voluntat d'ajudar-se un mateix, la disposició d'acceptar i fer un ús racional de l'ajut extern acaba per desaparèixer.

Fins ara la preparació per a la vida laboral que hom tep dels sistemes educatius ignora en gran part la possible realitat de l'atur i de la feina insegura ocasional. Molts mestres es mostren reticents a tractar aquest tema a classe. Per aquest motiu, quan deixen l'escola, els joves no disposen ni tan sols d'una informació bàsica mínima sobre què han de fer si es troben sense feina. Com fer una sollicitud, on anar-se a apuntar, com demanar el sub. sidi d'atur, com omplir el temps liture... Es deixa sol l'individu amb una gran quantitat d'interrogants que són el resultat d'una preparació insuficient per fer front a un nombre limitat d'oportunitats d'aprenentatge i opcions restringides de llocs de treball.

La Liure elecció de professió i lloc de treball és una part dels drets bàsics de la persona en els països de la Comunitat Europea. Això no vol dir tanmateix que a tot arreu de la Comunitat hi hagi una gamma completa de possibilitats d'aprenentatge dins el món de la feina i una plena varie. tat de tipus d'ocupació. Hi ha regions en cada país en què les alternatives són notablement escasses encara que l'oferta total de treball i oportunitats d'aprenentatge pugui ser suficient: a algunes àrees rurals es produeix una manca de mà d'obra no resolta, però limitada només al camp de l'agricul- 
tura, mentre que un altre tipus d'oportunitat és escàs; hom troba situacions semblants en altres àrees de la indústria o el comerç dedicades exclusivament a una sola activitat.

Allà on hi ha alternatives de feina, encara que siguin inadequades, molts joves a la recerca de feina han de sotmetre lliturs interessos i inclinacions personals a les lleis del mercat laboral local. Sovint han de renunciar a feines que no entren dins el patró laboral local a causa que les oportunitats a l'abast d'aprenentatge reflecteixen en gran part l'estructura laboral de la localitat. Les possibilitats de trobar oportunitats adients en una altra zona es limiten moltes vegades perquè la possibilitat de desplaçaments a aquesta edat no acostuma a anar més enllà d'anar i tornar cada dia a casa des del lloc de treball o aptenentatge.

Així, molts joves, o bé ban de realitzar liurs esperances personals respecte a la vida laboral dins el marc limitat de les oportunitats locals, o bé es veuen obligats a agafar una feina o un aprenentatge que no correspon a llurs ambicions. En ambdós casos la transició al treball és marcada per una relativa pèrdua, ja que la societat fa néixer esperances que més tard no es poden realitzar. Cal enfrontar-se als requisits de la feina $i$ aprendre noves normes.

El fet d'haver aconseguit un lloc de treball o d'aprenentatge no marca la fi del període de transició d'un jove: lluny d'això, comença una altra etapa de la transició. Abans de començar el treball o la preparació pràctica dins el treball, molts joves mai no han tingut cap experiència dels requeriments que dibuixen en la pràctica el perfil de la seva feina. La qüestió de si seran capaços o no de fer front a aquestes exigències només es pot resoldre en la pràctica. Els certificats de l'escola no en són bons indicadors, tal com l'experiència ha demostrat constantment. Cada vegada més seleccionadors es miren els títols només com un ajut a l'hora de fer una primeta selecció; es concedeix molta més importància al període de prova (particularment dins les grans empreses) $i$ als tests d'aptituds especials quan s'ha d'avaluar la preparació dels joves.

En deixar l'escola, els joves sovint comencen a treballar amb la creença que eis títols oficials que tenen o la vocació que ha anat creixent en ells per una específica professió o lloc de treball constitueixen una base suficient per a garantir l'exit un cop dins l'ocupació real. En la pràctica han de fer front a un abisme considerable entre llurs aspiracions i la realitat. A més, algunes de les aptituds $i$ alguns dels coneixements que el treball requereix s'han tractat poc o gens a l'escola. Així, per exemple, produir constantment un rendiment determinat durant un periode donat de temps, fer front a una pressió psicològica durant diverses hores al dia, tenir responsabilitats personals sobre el material i la maquinària, possiblement són factors que 
produeixen molt stress als joves que no han tingut cap feina abans. Molts d'aquells que han passat per una educació professional específica, sobretot en estudis de plena dedicació, han d'adonar-se que es requereix la pràctica d'una sèrie de coneixements professionals que no eren cap element explícit del seu aprenentatge previ. A més, certes aptituds ja adquirides poden no tenir aplicació pràctica dins la feina. Això pot afectar tant les aptituds professionals com d'altres coneixements. Així, els joves han de fer front a la realitat d'un treball on, per exemple, hi ha parts de llurs aptituds que resten per desvetllar per manca d'incentius, o on l'àmbit de la iniciativa personal i la participació activa en la resolució dels problemes es veu limitat per una rutina del treball altament mecanitzada. Un lloc de treball massa dur o massa poc exigent condueix amb freqüència a la insatisfacció i la desillusió.

No només cal un cert nivell educatiu i professional per a fer front a les exigències del lloc de treball; cal entendre uns altres esquemes de comportament $i$ cal aprendre unes altres normes. Es durant el primer periode en la feina que molts joves s'enfronten cara a cara a una nova classe de solidaritat que és diferent de la del món extern. Han d'aprendre, per exemple, a negociar les seves condicions laborals, ja sigui personalment o a través dels sindicats, i a sospesar els seus interessos personals amb els del grup de companys; a acceptar la disciplina de grup sense caure, però, en el conformisme; a entendre què signifiquen en realitat els drets del treballador. Sovint els altres companys esperen que es comportin com a adults, sense que els joves puguin estar a aquesta alçada. Aquest stress pot fer augmentar fàcilment les dificultats dels joves a I'hora de guanyar confrança en ells mateixos, $i$ adquirir les actituds personals $i$ de companyonia que necessiten a l'hora de guardar llur autonomia personal durant aquesta nova etapa.

Lluitar amb aquests problemes és en part una qüestió d'adaptabilitat i capacitat individual de suportar una pressió tan forta durant un pexíode donat de temps; també pot, tanmateix, posar en evidència la necessitat que tenen uns quants joves de pensar un altre cop en la decisió que ja han pres en favor d'una professió o tipus de feina específic i fer-ne prendre una altra. Com més poc s'ha començat des d'una posició personal amb objectius ben meditats respecte a la vida laboral, més difícil es fa no només el fet de resoidre algunes de les pesades exigències laborals, sinó també poder trobar una alternativa millor. 


\section{QUAN ES PRODUEIXEN ELS PROBLEMES?}

Els problemes de la transició de l'escola al món laboral no només es limiten al lapse de temps entre la fi de l'escolarització i el començament de la primera feina. Surten a la llum amb més frequèència durant aquest període, però molt sovint els seus orígens se situen en una etapa anterior i alguns d'ells només es fan evidents després del primer periode laboral. Per aquest motiu, sembla que serà raonable de fer una distinció de les etapes diferents on hom pot esperar trobar els problemes de la transició.

\subsection{L'etapa preparatòria mitjançant l'educació secundària}

Una sèrie de decisions que afectaran la posterior transició a la vida laboral s'han de prendre durant els anys d'educació secundària. Per als joves i també per als seus pares, sovint allò que aquestes decisions impliquen no és prou clar en el moment en què s'han de prendre. Una complicació més greu és el fet de no poder tornar endarrera un cop algunes d'aquestes decisions ja han estat preses. Malgrat que en teoria, per exemple, si cal repensar-se allò que s'ha triat originàriament, tots els sistemes educatius ofereixen oportunitats de fer el pas d'un tipus d'estudis a un altre, generalment, en la pràctica, als joves els és molt difícil de superat un problema d'aquest tipus.

A alguns països, particularment allà on l'educació global no és la nota dominant, cal prendte decisions ja des del pas de l'ensenyament bàsic al primer cicle d'ensenyament secundari, és a dir, a una edat compresa entre els deu $i$ els dotze anys. Normalment, en aquests casos es pot escollir entre tipus distints d'escola orientats a assolir nivells diferents de preparació i titulació. Malgrat que s'està duent a terme un esforç en aquests països per tal d'aconseguir, si més no, una mínima coherència entre els diferents corrents del primer període de l'educació secundària, encara roman una marcada tendència a la diferenciació. L'elecció del tipus d'escola té con. seqüències a l'hora de l'accés de la persona a estudis especialitzats de les següients etapes educatives. Al mateix temps, es pren prèviament una decisió pel que fa a les futures alternatives després de l'escolarització obligatòria: alguns tipus d'escola posen l'accent en els corrents més acadèmics que condueixen fàcilment a l'educació superior, mentre que d'altres s'orienten més a la transició, a la formació professional o al treball immediatament després d'acabar. En alguns països, les decisions que hom ha de prendre després d'acabar l'educació bàsica primària impliquen una elecció immediata en favor de corrents distints d'educació general o global o d'uns quants 
corrents d'educació professional. Haver escollit això últim implica moltes vegades una decisió prèvia en relació a la futura matèria en què es treballarà o a l'especialització.

Posteriorment, els joves que ja han arribat a l'edat establerta d'haver acabat l'escola però que encara no ho han fet es troben en un altre conflicte. Aquesta situació pot haver estat el resultat d'haver repetit un o més anys d'escola anteriorment; a alguns sistemes això pot afectar àdhuc els joves que han anat passant sense repetir cursos; per exemple, quan l'edat establerta per a acabar és més baixa que l'edat en què els estudis poden realment estar fets. Malgrat que la major part dels joves es decideixen a acabar els estudis, encara n'hi ha alguns que se senten temptats a deixar I'escola abans d'hora. Això és especialment cert en aquells que van malament o que no tenen cap motivació per a romandre en un ambient escolar; aquests joves que deixen l'escola prematurament molt sovint passen a formar part del grup de risc més important del període de transició.

\subsection{El periode entre la fi de l'escola $i$ el començament de la primera ocupació}

Molts joves fan plans per entrar a treballar o per a l'aprenentatge pràctic dins el món laboral quan encara van a l'escola. Tanmateix, molts acaben l'escola sense idees clares sobre el futur d'aquests plans o sense cap oferta real. Comencen la vida labotal com a joves en atur. En la pràctica un període curt serse feina es pot fer servir en moits casos per a donar temps a l'orientació personal d'aquells que encara no tenen preses llurs decisions. Els estudis sobre això demostren el fet significatiu que, en comparació amb els joves en atur, els que treballen sovint ja van prendre llurs decisions quan encara eren a l'escola, mentre que, en un gran percentatge, els joves sense feina encara no s'havien decidit. Pet això, per a molts joves en atur el primer període després d'haver deixat els estudis és una etapa de reflexió sobre liurs orientacions personals que durant els anys d'escolarització no varen poder tenir.

Després del primez període d'atur, durant el qual l'individu afectat demostra generalment una gran activitat en la investigació de les possibles oportunitats de feina o aptenentatge, la situació empitjora ràpidament sí res d'això no té èxit. Tot el complex de greus problemes personals, socials i econòmics esdevé una tealitat pet a aquells joves que no són capaços d'establit-se en una feina durant un període més llarg, ja sigui per incapacitat personal o per manca d'oportunitats. 


\subsection{Els primers anys de treball}

Respecte als diferents períodes en què tenen lloc els problemes de la transició hom pot distingir dues etapes principals durant els primers anys d'ocupació, les quals etapes són la d'iniciació al treball i la d'establiment en la feina o professió que hom ha escollit.

Durant l'etapa inicial (que pot incloure un període d'aprenentatge pràctic; per exempie, fent d'aprenent) la idoneitat personal per al treball o professió es posa sota consideració i examen tant dels joves com dels em. presaris. Tota la qüestió de satisfer les exigències de la feina i de desenvolupar o completar les aptituds necessàries es planteja durant aquest període, juntament amb la possible reconsideració de les decisions que ja s'han pres.

Després de l'inici en la feina, l'etapa d'establiment dins l'ocupació encara comporta alguns riscs abans d'acabar amb èxit la transició. És sobretot a aquest nivell que els joves han adquirit experiència suficient per a valorar llurs pròpies necessitats i seguir l'evolució dels valors i requeriments de llur professió, així com per a comprovar quan sigui necessari si llurs aspiracions són encara realistes. De fet, per a molts joves treballadors aquesta pot ser la darrera oportunitat de pensar en un retorn temporal a l'educació o l'aprenentatge per tal de completar llur formació i llur competència professional. Per suposat, hom ha de fer front al canvi i la flexibilitat en el decurs de la vida professional. Però, malgrat que la idea d'una formació que duri tota la vida està cada vegada més d'acord amb allò que preveuen eis mitjans pràctics, els requisits previs bàsics per a adaptar-se als futurs canvis i fer ús de les perspectives de futur s'adquireixen durant el període de transició i són difícils de guanyar en la maduresa.

\section{QUINS FACTORS INCREMENTEN LES DIFICULTATS DE LA TRANSICIO}

Les subseccions que segueixen pretenen agrupar $i$ analitzar amb més detall els factors que tenen una influència dins el problema. Tenir consciència d'aquests factors és essencial a l'hora de planejar mesures diferenciades $i$ efectives per a ajudar els joves durant el període de transició.

Aquesta anàlisi no ha estat pensada per a establir una connexió causal sòlida entre els distints factors d'influència $\mathrm{i}$ les dificultats pràctiques de la transició. Més aviat intenta d'estructurar tota la gamma de possibles variants, facilitant així una visió general d'aquest complex problema. 


\subsection{Punts dèbils de les condicions del marc estructural}

Encara que gran part del context de les iniciatives i activitats personals respecte a la preparació per a la vida laboral no és gairebé mai sota el control de l'individu, és tanmateix important ésser conscient de quines són les condicions estructurals que afecten la tranquilititat de la transició de l'escola al treball. A aquelis qui són dins la transició, una comprensió clara del context els ajuda a construir una perspectiva laboral significativa a l'hora de valorar allò que realment pot fer l'individu per solucionar els problemes que va trobant. A aquells qui tenen responsabilitats d'ajut en el període de transició, la consciència dels punts debils de l'estructura contextual els pot ajudar a planejar les mesures a prendre, i a establir unes prioritats.

\subsection{L'impacte de les condicions sòcio-econòmiques contextuals}

Una primera sèrie important de factors contextuals està relacionada amb les condicions sòcio-econòmiques generals. Aquestes condicions formen una estructura complexa, els elements de la qual, malgrat ésser interdependents en part, no entren dins una sola secció de la política de responsabilitat. Una indicació aproximada d'alguns aspectes pot illustrar la seva influència en la transició:

- Evidentment, una crisi generalitzada o una disminució del creixement econòmic influeix en les perspectives immediates d'aquells qui han acabat l'escola i busquen el primer lloc de treball. Els joves que ja treballen, especialment en feines marginals, $i$ aquells amb poca o gens especialització estan exposats amb més freqüència que els adults a l'acomiadament, sobretot quan es concedeix prioritat a salvar els llocs de treball d'aquells qui han de mantenit una família.

- El canvi tecnològic a gran escala pot tenir un efecte similar (per exemple, disminuint la demanda de mà d'obra com a resultat de la reconversió i de l'exigència de coneixements en noves disciplines i reduint així particularment el nombre d'oportunitats dels més poc preparats).

- Punts dèbils de la infrastructura regional. Les oportunitats que ofereixen les àrees l'economia de les quals es basa en una sola activitat (per exemple, àrees agrícoles o mineres) sovint es limiten a la sèrie de tipus d'ocupació o aprenentatge de la regió. Així els canvis estructurals en l'activitat econòmica predominant poden significar un índex d'atur més elevat en aquestes zones, independentment de la situació general a la resta del país. 
- L'organització i el control del mercat laboral pot tenir una influència considerable en el pas dels joves al treball. A les regions i els països en què l'harmonia entre l'oferta i la demanda és una tasca que s'ha deixat tradicionalment sobretot a la iniciativa de les parts directament afectades (és a dir, els empresaris i el jovent), la situació real del mercat laboral és difícil de valorat. Ni les places vacants ni els joves en atur estan enregistrats moltes vegades; els serveis de collocació i de cooperació i guia professional han de treballar sobre les bases limitades de les suposicions personals i el coneixement particular dels individus afectats més que sobre dades fables. Per això les alternatives reals que puguin existir poden no ser posades en coneixement dels joves, que normalment només accedeixen a una informació limitada de les oportunitats que hom ofereix.

A més, poden sorgir oportunitats en un metcat negre o secundari de mà d'obra que no està prou ben organitzat per a oferir cap perspectiva a llarg termini als aturats.

En aquells pailsos o regions on s'obliga o s'incita prou els joves a enregistrar-se, si més no hom té a l'abast informació sobre els treballadors, la qual informació es por utilitzar per a la planificació de mesures específiques d'assessorament i ocupació. Al mateix temps, això també pot estimular els empresatis a entegistrar llurs vacants de feina per tal d'obtenir uns candidats al lloc de treball més adequats, mitjançant l'ajut de les agències.

- La composició de la força laboral és diferent segons els paisos i les regions. La piràmide de població respecte a l'edat no és la mateixa a tot arreu. En aquells llocs on, en relació a la mà d'obra adulta, els joves tenen una representació més àmplia o on el seu nombre creix desproporcionadament, els joves que busquen la primera feira troben una competència més dura i un accés al treball més difícil que en situacions en què el total de mà d'obra juvenil decreix. Les variacions en la quota de naixements infiveixen en això, així cota l'afluència de treballadors immigrats o temporals i qualsevol increment en la proporció de noies que entren dins el mercat Iaboral.

- La xarxa de la seguretat social i dels serveis d'ajut públics és un factor essencial que pot ajudar els joves i llurs famflies a resoldre alguns dels problemes de la transició. El fet de si els joves tenen o no dret a subvencions per a un aprenentatge adequat o més ensenyament és de vegades un criteri decisiu a l'hora d'escollir entre una entrada prematura dins el treball no especialitzat o la possibilitat d'obtenir un títol professional; el fet de rebre o no subsidi d'atur té una impartància decisiva per al jove quan totes les alternatives que té consisteixen a agafar el primer lloc de treball que se li ofereix o buscar i escollir la feina que més s'adigui amb les seves aptituds $i$ aspiracions personals. 
- L'existència de programes especials, com els collectius de serveis o projectes d'experiències laborals pràctiques, no soluciona un problema d'atur juvenil, però en molts casos ajuda els joves a omplir el periode de temps entre que deixen l'escola i troben una ocupació estable. Al mateix temps, uns programes així poden contribuir activament a una adequada preparació per a la vida laboral mitjançant la creació de situacions d’aprenentatge que permeten a l'individu de ser més conscient de les seves tendències i la seva capacitat personal i d'adquirir les aptituds que hom necessita en el món teal del treball.

\subsection{Diferències entre els sistemes i tradicions educatius}

Una segona sèrie de condicions del marc estructural està relacionada més directament amb les responsabilitats i característiques dels sistemes educatius. Les distintes estructures i tradicions educatives dels països de la Comunitat Europea influeixen en els problemes de la transició de maneres diferents:

- L'administració $i$ la competència pet a prendre decisions se centralitzen algunes vegades $i$ arriben a esdevenir obstacles a l'hora d'emprendre accions flexibles, adaptades a les necessitats específiques dels sistemes educatius formals locals o regionals. En d'altres casos, les possibles oportunitats d'actuació potser no són aprofitades per part de les administracions o escoles locals perquè no tenen prou poders per a fet-ho. Les estructures que gaudeixen d'una àmplia descentralització dels poders decisoris sovint faciliten la planificació i la implantació d'activitats molt adaptades a les possibilitats i requeriments locals. Pexò, si no s'incorporen clarament en un marc educatiu general ben coordinat, algunes activitats originals corren el risc d'esdevenir iniciatives aillades. Per això és important que hi hagi un equilibri raonable entre els poders centralitzats $i$ els descentralitzats.

- En alguns països l'educació general i la professional pertanyen a un mateix ministeri, mentre que en d'altres cauen sota la responsabilitat d'administracions diferents. En molts päsos les empreses també disposen d'algun tipus d'aprenentatge professional, el qual va des de programes limitats d'iniciació a la feina fins a estudis complets de formació, generalment amb poca relació amb el sistema d'educació professional de l'Estat. A més, existeixen diversos tipus de responsabilitat mixta (per exemple, l'aprenentatge a Alemanya) basats en la idea d'una estreta collaboració entre les 
institucions acadèmiques i les empreses que ofereixen aprenentatge dins el lloc de treball.

Allà on tota la responsabilitat és a una sola mà, tant pel que fa a l'educació general com pel que fa a la professional, això facilita la collaboració entre ambdós sectors. L'establiment de prioritats per als dos sistemes pot fer-se així d'una manera més uniforme i harmònica, la qual cosa fa més fàcil la transició dels estudiants de les institucions d'educació general a les de formació professional. Els canvis i les innovacions en la relació entre ambdós sistemes no es veuen així frenats per interessos divergents. Allà on la responsabilitat es reparteix entre diferents ministeris o està més en mans de l'administració que de l'educació, es produeixen problemes de coordinació i collabotació, però potser també hi ha més đlexibilitat per a adaptar el contingut i l'estructura de l'educació professional a les necessitats dels diferents sectors de la societat i l'economia (per exemple, la sanitat o l'agricultura). Generalment, sembla que hom té un concepte més ampli de l'educació professional en aquells llocs en què ha estat instaurada per part de l'Estat, els nivells dels certificats semblen ser més homogenis i la provisió d'escoles professionals $i$ equipaments no es veu $\tan$ afectada per crisis cícliques. Tanmateix, un problema que sovinteja molt a les escoles estatals de formació professional és la manca de pràctica laboral real en el pla d'estudis. Adhuc els estudiants qualificats troben dificultats a l'hora d'aconseguir un primer lloc de treball si no tenen experiència pràctica.

Aquest perill amenaça molt menys els joves dins dels programes d'aprenentatge orientat al treball que ofereixen algunes empreses. Aquests joves troben feina molt més fàcilment després d'haver acabat aquests estudis. El contingut i l'amplitud de la formació professional a les empreses, tanmateix, sovint es limiten a àrees de coneixement molt específiques. La coordinació de les diverses branques sovint és insuficient, la qual cosa pot reduir la flexibilitat de l'aprenentatge rebut. El fet que hi hagi la quantitat suficient de llocs d'aprenentatge depèn en gran part de la iniciativa de les empreses privades, i els nivells de qualitat de l'aprenentatge poden variat molt de l'una a l'altra.

- Dins de l'educació general i fins a cert punt també dins la professional hi ha diferències considerables pel que fa a la rigidesa de cada sistema i a l'edat d'optar entre diferents possibilitats. La possibilitat de passar d'una opció a l'altra, que en teoria existeix a molts sistemes, canvia molt en la pràctica. Així els joves d'un país es poden veure frenats per haver escollit malament entre tota una sèrie de carreres quan tenien tretze anys; en d'altres això no passa fins els setze anys, en què hom pot esperar una decisió més madura.

- La natura i el grau d'importància que hom concedeix al sistema 
d'avaluació i atorgació de títols varia considerablement segons els països. En alguns, bàsicament, hi ha un certificat que diu que hom ha acabat els estudis d'educació secundària; quan per poder acabar cal repetir cursos, molts joves deixen l'escola sense cap títol. D'altra banda, a alguns països es fa un examen quan s'acaba l'educació obligatòria, que a vegades és d'un nivell tan alt que moltes persones són eliminades. La durada de l'escolaritzación obligatòria a dedicació completa varia segons els països. En alguns arriba fins als 14 anys $i$ en d'altres fins als 15 o 16. Per a molts adolescents, aquest petíode (dels 15 als 16 anys) és aquell en què comença a desaparèixer la inestabilitat i la vida es comença a enfocar d'una manera més madura. Particularment, aquesta maduresa és important pel que fa a saber escollir una professió $\mathrm{i}$ decidir si seguir estudiant o no.

- L'abast i l'adequació tant de l'educació secundàtia superior com de la formació professional, juntament amb els plans de suport financer, va. rien considerablement d'un país a l'altte i àdhuc sovint d'una regió a una altra del mateix país. Així, l'accident geogràfic del lloc de residència pot afectar des del començament les possibilitats que tenen els joves per a obtenir l'educació que necessiten per tal de satisfer liurs aspiracions.

- Potser la variació més important entre paísos i entre llurs regions és la naturalesa i la quantitat de serveis d'otientació i assessorament. A alguns països aquests serveis estan molt poc avançats tant a les escoles com fora d'elles; en d'altres un servei extern no troba cap cortespondència en una organització adient dels estudis en els plans escolars. Així els joves d'algunes zones es veuen al marge de tota informació sobre la situació laboral local, mentre que els d'altres àrees es troben mal preparats per a utilitzar aquestes informacions.

\subsection{Participació dels poders públics i els privats en la millora de la transició $i$ cooperació entre ells}

La responsabilitat de preparar els joves per a la transició i d'ajudar-los durant aquest petíode no és només una qüestió que pertanyi als sistemes educatius. Adhuc les iniciatives que hom emprengui dins el camp de l'educació només poden tenir uns efectes limitats si no troben el complement i el suport actiu de persones $i$ agències fora d'aquest terreny. Els punts següents poden illustrar alguns factors que influeixen en les possibilitats d'acció conjunta:

- Hom considera que la manca de coordinació i collaboració entre l'educació i altres polítiques sectorials a nivell local, regional i nacional 
contribueix a la disparitat entre la preparació i els títols que les escoles i institucions de formació professional atorguen i els que realment exigeixen el mercat laboral $\mathrm{i}$ els diversos sectors de l'economia. Les mesures educa. tives especials pensades per a posar remei a aquesta disparitat sovint troben una competència innecessària en les iniciatives que es posen en marxa dins una altra part de la política, que persegueix objectius molt semblants però funciona sota regulacions administratives i financeres bastant diferents (per exemple, els programes educatius per a joves que han fracassat a l'escola contra els plans de preparació laboral organitzats per aquelles autoritats que s'encarteguen de la regulació de la mà d'obra). Així la manca de coope. ració porta al fracàs en la combinació dels millors plantejaments en els diferents sectors de l'actuació política.

- La manca de relació entre les institucions educatives, per una banda, i la comunitat circumdant, per l'altra, pot així considerar-se un obstacie molt important per al desenvolupament d'una consciència collectiva més àmplia en la resolució del problema de la transició. Sense cap lligam amb les institucions educatives, la majoria de pares no són capaços d'acomplir Ilurs responsabilitats de completar la preparació dels joves per a la transició. Molts pares no se senten motivats a participar en l'escola i moltes escoles no volen aquesta participació. La collaboració activa en la tasca de l'escola pot portar els pares a una millor comprensió de les dificultats que els setus fills hi troben $i$ així els pares $i$ els mestres podrien compartir els uns amb els altres la responsabilitat de la preparació per a la transició. Igualment, els empresaris $\mathrm{i}$ els sindicats se senten poc afectats sobre allò que passa als joves que encara van a escola.

- La inducció al treball concebuda d'una manera estreta i els programes de preparació dins la feina fracassen en seguir fomentant i com. plementant allò que els joves ja han après a l'escola. Un esforç més intens dels empresaris $\mathrm{i}$ els sindicats per a entendre les deficiències, així com el potencial desenvolupament dels joves que han acabat l'escola, juntament amb una collaboració i un feedback a les institucions educatives i serveis d'assessorament, podrien facilitar considerablement l'entrada dins el món laboral. Sobre aquesta base poden sorgir més fàcilment idees per a la iniciació a la feina i l'aprenentatge en el treball, les quals respondran millor a les necessitats dels joves $\mathrm{i}$ els podran ajudar a realitzar altres aspiracions i motivacions personals. 


\subsection{Deficiències en la naturalesa de la provisió existent $i$ en la capacilat individual d'utilitzar-la}

Els joves sovint pateixen d'una mancança dels mitjans personals que necessiten per a fer la transició amb èxit. Aquesta mancança prové en part de la naturalesa inadequada de les provisions educatives i en part de llur fracàs a l'hora d'aprofitar els avantatges d'ailò que se'ls ofereix.

Si hom examina les qualitats personals que els joves necessiten a l'hora d'escollir, aconseguir i conservar un lloc de treball, de fer front a la vida adulta $\mathrm{i}$ àdhuc a l'atur, s'observa que l'educació normalment només sap ajudar en part a assolir-les. En general, aquestes qualitats inclouen: actituds $i$ dots personals $i$ interpetsonals, per exemple la confiança en un mateix, el coneixement d'un mateix, l'esperit de collaboració i la iniciativa; qualitats per a fer front a la vida diària de la nostra complexa societat, per exemple saber utilitzar els mitjans de transport i comunicació; capacitat de resoldxe problemes i artibar a conclusions i decisions lògiques; una alfabetització bàsica de tipus pràctic $i$ un coneixement $i$ una comprensió reals de la naturalesa, els estímuls i les limitacions dels diferents tipus de feina.

Una manca d'aquestes qualitats pot portar a escollir uns estudis equivocats o unes assignatures dels estudis generals i professionals per a les quals el jove no té la capacitat adient o que no el duen a la vida professional que ell desitja. També pot portar a un ús inadequat dels ajuts i assessoraments que hom li ofereix. Sense una vexitable comprensió dels diferents tipus de feina no es pot agafar la informació especifica sobre les oportunitats de treball $i$ les diferents carreres, perquè no es disposa d'un matc on enquadrar-la.

El fracàs en fer una provisió de situacions d'aprenentatge que portin a adquirir aquestes qualitats prové en part d'una manca de comprensió sobre què és allo que els joves necessiten per a la transició, $i$ en part de l'actitud acadèmica innata dels mestres. Això a la vegada sorgeix d'una preparació insuficient dels mestres $i$, a més, d'una manca dels serveis per a reciclar eis mestres, per a donar-los una comprensió de la naturalesa i la importància de la preparació per a la transició i per a capacitar-los per a inventar i practicar situacions d'aprenentatge que ajudin a l'adquisició d'aquestes qualitats.

No tota la culpa de la manca de mitjans personals adequats la tenen els sistemes educatius. Els joves, en especial aquells que passen les angúnies de l'adolescència, poden tenir altres preocupacions fora del món acadèmic o poden ser mandrosos $i$ apàtics $i$ no assolir les qualifacacions, els certificats que necessiten per a la feina. Això ens fa reconsiderar la na- 
turalesa i la finalitat d'una qualificació a una etapa tan dificil: ¿s'hauria de fer servir això com un mitjà de pronòstic o de selecció? ¿S'haurien de concedit oportunitats als joves més endavant per tal que obtinguessin el títol?

Moltes vegades els joves, especialment els de nivells sòcic-econòmics més baixos, no poden resistir les pressions del grup: deixar l'escola, trobar una feina; en molts casos qualsevol feina. Això fa que no escullin bé, que no assisteixin a les sessions d'assessorament i no tinguin en compte els consells que allà es donen.

\subsection{Conceptes erronis a les perspectives personals de la transició i la feina}

Ja s'ha descrit la realització de les expectatives $i$ aspiracions personals per a la vida laboral i adulta com una condició necessària per a fer la transició amb èxit. Hom pot adduir que la sola existència d'aspiracions amb un potencial d'evolució activa és àdhuc més important que llur naturalesa real. Per tal d'ésser les directrius de llur vida futura, les actituds $i$ els valors dels joves no cal que siguin, $i$ de fet moltes vegades no ho són, els mateixos que aquells que dominen actualment a la societat adulta. No obstant això, les idees errònies estereotipades, tant si han estat adoptades pels adults com si han sortit dels joves mateixos, condueixen a una falsa orientació o a un carretó sense sortida. Les idees errònies també poden haver sorgit per la manca d'informació $\mathrm{i}$ experiència. EI desenvolupament dinàmic de la comprensió $i$ les aspiracions hauria, doncs, d'ésser encoratjat, basant-lo en una avaluació crítica tant de la tealitat existent com de l'esperat futur. De fet, una proporció considerable de joves arriba a l'edat d'acabar l'escola sense tenir ni una idea clara sobre quins són els passos que tot seguit han de fer en la transicio, o amb idees errònies. Aquests fenòmens es veuen reforçats per una sèrie de factors entre els quals s'incloven els següents:

- Una manca de comprensió de les diverses funcions (i també d'algunes disfuncions) que el treball té o pot tenir en la vida adulta i adolescent. El potencial de treball que ha d'integrar-se a la societat, sobretot en l'adolescència, destaca la dificultat de les eleccions en aquest periode. No totes les ofertes ni de bon tros ofereixen una sortida suffcient a la realització personal; molts són treballs sense sortida, amb perspectives molt limitades. Sembla que molts joves veuen el fet de conformat-se amb aquesta situació com l'única mesura per evitar l'amenaça de l'atur, si més 
no de moment. Una visió menys fatalista $\mathrm{i}$ una percepció més dinàmica del treball com un element important però no immutable de tota la dinàmica de l'evolució de la vida, podria ajudar-los a mantenir $\mathrm{i}$ incrementar tant la motivació com la capacitat de fer una valoració més crítica de les oportunitats a l'abast $i$ a buscar $i$ considerar alternatives que proporcionin unes estructures millors per a una transició satisfactòria.

- Una manca general de motivació pel treball i l'aprenentatge. Això està Iligat arnb allò que hem dit abans. Molts joves que finalment acaben l'escola troben que això és una bona experiència per a ells; al mateix temps alguns se senten frustrats perquè els llocs de treball que troben no tenen cap significat. Això es tradueix amb freqüència en actituds negatives tant contra la continuació de l'educació com contra la feina. La transició a la vida laboral no ofereix cap objectiu nou a aquests joves. Si la societat acceptés llur problema com una situació invariable o l'ignorés, es facilitaria el desenvolupament d'una subcultura jove, que finalment conduiria els seus membres a una distància insalvable de la resta de la societat. No sembla que reorientar els joves no motivats cap a les provisions existents d'educació o feina sigui una solució suficient. Hom ha de reconsidetar nous plantejaments, basats en una anàlisi més acurada i en una comprensió més profunda de les raons d'aquesta manca de motivació. Com a punt de partida sembla important acceptar els joves tal com són per damunt del requeriment d'«actituds realistes». Hom pot observar els primers signes d'un interès creixent pel treball o per tornar a estudiar en alguns casos en què han progressat algunes alternatives a allò que hi ha establert.

- El fenomen molt comú de l'orientació vers un camp massa limitat de professions $\mathbf{i}$ un èmfasi excessiu en l'attactiu de determinats llocs de treball. Això amb freqüència es troba a ''arrel d'algunes de les dificultats dels joves a l'hora de trobar feina, en alguns casos fins un lloc d'aprenentatge. Les aspiracions professionals i per tant l'elecció d'una professió sovint es veuen massa influïdes per l'atractiu de les feines més de moda. Per aquest motiu, la «superproducción en certes especialitzacions pot portar a una competència molt duta en aquests camps i molts joves poden veute's obligats a trobar feina en altres sectors diferents d'aquell per al qual estan preparats.

- Una imatge massa estereotipada de la posició de l'home i la dona dins la societat. Malgrat que durant el passat recent s'han fet esforços importants per tal d'assegurar la igualtat d'oportunitats a ambdós sexes, les imatges tradicionals encara persisteixen a tots els països. El paper diferent tradicional segons el sexe és encata un factor innegable que influeix notablement en les eleccions de la feina $i$ els estudis per part dels joves. 
La majoria de noies segueixen prenent decisions que es basen més en el seu futur paper en el si de la família que en les aspiracions per a la vida laboral. La preparació laboral no es veu moltes vegades com una necessitat vital, ni per part de les noies mateixes ni per molts altres membres de la societat. Aquestes conceptes erronis es tradueixen en efectes inquietants si passem a la desproporció de la xifra de joves aturats de sexe femení.

En relació amb tots aquests factors s'ha trobat que el context general social $i$ econòmic en què creixen els joves $i$ especialment la naturalesa de llurs relacions socials amb els amics, Ia família i la comunitat tenen una importància vital en l'evolució d'un pla personal per a la seva vida futura. Per mitjà de remeis educatius a curt termini només es pot intentar reduir els efectes negatius que els punts dèbils de la societat tenen sobre les actituds dels joves i llurs aspiracions per a la vida laboral; les mesures només dins el camp de l'educació no poden substituir la força que un mitjà social sòlid pot oferir per al desenvolupament d'unes perspectives dinàmiques de futur.

\section{COM AFECTEN ELS PROBLEMES ELS DIFERENTS GRUPS DE PERSONES?}

Les diverses dificultats de la transició no afecten tots els joves igual; alguns són més vulnerables que altres. Tanmateix, només un nombre limi. tat de joves pertany a un grup de risc per naturalesa, per exemple per una deficiència física o mental. La majoria d'aquells que durant la transició han esdevingut vulnetables han sofert infuències negatives que, tant si són el resultat de diverses condicions contextuals adverses, com de la mancança de mitjans individuals o d'equivocacions en les aspiracions, poden acumular-se i canviar amb el temps. Per això el grau de vulnerabilitat dels joves és el resultat d'una combinació particular dels factors que els influeixen nega. tivament $\mathrm{i}$ no és necessàriament només una qüestió de pertinença a un grup social concret.

La definició de grups de risc en concret és difícil i les categories de cap manera no són inflexibles. Tanmateix seria possible de fer una tipologia bàsica segons les dificultats que experimenten els joves, que són degü. des a:

- Llur posició dins la societat. Aquesta categoria inclou grups tan diferents com les noies, els qui tenen greus desavantatges socials, els emigrants i immigrants $i$ aquells qui pateixen alguna deficiència física o mental. 
EI problema comú més important de tots ells és que sovint el comportament $i$ les actituds plenes de prejudicis d'altres membres de la societat els afecten seriosament. Siguin quines siguin les seves qualificacions i aptituds, aquests grups tendeixen a ser els primers perjudicats per l'atur, que és més llarg per a ells; se'Is ofereixen més poques oportunitats reals que als altres quan entren a la vida laboral.

- La naturalesa de la seva preparació per a la transició i la feina. Hom pot distingir dues subcategories. La primera abasta els joves amb una preparació insuficient. En són exemple els joves que han deixat l'escola sense cap qualificació o que així ho faran. Els problemes més greus d'aquest grup es reflecteixen en una mancança d'aptituds generals i pro. fessionals així com de la preparació que exigeixen molts llocs de treball amb perspectives de futur.

La segona subcategoria la formen els joves amb una preparació inadequada. Podríem incloure en aquest grup aquells que tenen un títol, però que no el poden fer servir, per exemple per una demanda insuficient d'aquesta especialitat a l'àrea local.

- La naturalesa de lluts aspiracions i valors. Aquest grup inclou sobretot els joves amb poca motivació i aquells que tebutgen explícitament els valors predominants de la societat. Aquests joves sovint no accepten les ofertes que els fan per a la transició al treball perquè els sembla que no tenen cap sentit per a ells.

Fins a quin punt $i$ com es pot ajudar els joves efectivament amb arranjaments dins el carnp de l'educació i si aquest ajut és tealment possible és encara matèria de controvertides discussions i d'una considerable incertesa. Les contractacions de gent per a solucionar això i la motivació per a continuat-ho es descriuen freqüentment com una dificultat bàsica inicial per part dels organitzadors d'aquestes iniciatives. Una segona dificultat consisteix a evitar una frustració $i$ un desencant encara més acusats dels joves que prenen part en aquestes accions després d'haver-les acabat. Un tercer problema és la imatge negativa de les accions d'ajut, que podria reforçar els conceptes negatius del mitjà social. L'experiència amb accions d'ajut és massa limitada per a portar encara a cap conclusió segura sobre la millor maneta de resoldre aquests problemes; s'ofereix massa poc ajut i massa fragmentat als grups més vulnerables i no hi ha prou coordinació entre les estructures existents per a fer afrrmacions concretes sobre l'eficàcia a gran escala dels programes especials. La definició de diversos tipus de vulnetabilitat ja implica dificultats en si mateixa, perquè la comprensió dels riscs que poden afectar els diferents grups no és independent d'un concepte dels valors i els objectius que els joves i la societat adulta poden no compartir. 
«Papers»: Revista de Sociologia

Si hom observa la quantitat i la interrelació extremament complexa entre els factors que poden causar dificultats en la transició, hi ha raons per a creure que molts joves poden esdevenir vulnerables en un cert periode de temps com a conseqüència d'una combinació específica de variants individuals $i$ socials. Sense qüestionar-nos el valor inherent $i$ la necessitat dels programes educatius d'ajut, l'experiència que d'ells es desprèn fa sorgir la qüiestió de si no seguirem perdent part de llur benefici més gran possible mentre no hi hagi un feedback continu des d'ells als corrents educatius principals que es tradueixi en més accions preventives sistemàtiques per a tots els joves. 